\title{
The Warrior on Claps from Tillya Tepe
}

\author{
P. Skupniewicz, K. Maksymiuk
}

For citation: Skupniewicz P., Maksymiuk K. The Warrior on Claps from Tillya Tepe. Vestnik of Saint Petersburg University. History, 2021, vol. 66, issue 2, pp. 567-584.

https://doi.org/10.21638/11701/spbu02.2021.215

Among the objects excavated in 1978 at the site of Tillya Tepe (Northern Afghanistan) by the Soviet-Afghan archaeological expedition led by Victor I. Sarianidi, the twin golden clasps from Burial III attract special and instant attention of any military historian or a researcher of ancient arms and armour. The identity of the personage(-s) on the Tillya Tepe clasps has quite rarely been studied. Scholars are usually satisfied with a generic term a "warrior". Kazim Abdullaev has identified the personage as Ares-Alexander. Jeannine Davis-Kimball has identified the personage as Enaree, the castrated priest of one of the epiphanies of Great Goddess. Patryk Skupniewicz supported the latter identification associating the personages from Tillya Tepe clasps with the North Indian, mainly Gandharan iconography of Skanda Kartikeya who, as a war-god, was an Indian equivalent of Ares. This article establishes the correspondence between the images on Tillya Tepe clasps with the representations of enthroned and armed goddesses which are quite common in the iconography related to the discussed clasps. The armed and enthroned goddess has been identified as the Iranian goddess Arshtat on Kushan coins. The warrior depicted on the golden clasps from Tillya Tepe should be interpreted as a portrayal of Arshtat, whose image was borrowed from the iconography of Athena. The goddess is shown seated on the throne with griffin-shaped legs known already in the Achaemenid times in the pose developed in the images in the late Hellenistic period, which is in line with the date of the entire site.

Keywords: Tillya Tepe, Central Asia, arms and armour, Alexander the Great, Arshtat, Enaree.

Patryk Skupniewicz - Postgraduate Student, Siedlce University of Natural Sciences and Humanities, 39, Żytnia str., Siedlce, 08-110, Poland; patryk.skupniewicz@gmail.com

Патрик Скупневич - аспирант, Университет естественных и гуманитарных наук в г. Седльце, Польша, 08-110, Седльце, ул. Жутня, 39; patryk.skupniewicz@gmail.com

Katarzyna Maksymiuk - Dr. Hab., Associate Professor, Siedlce University of Natural Sciences and Humanities, 39, Żytnia str., Siedlce, 08-110, Poland; katarzyna.maksymiuk@uph.edu.pl

Катаржина Максимюк - Dr. Наb., доц., Университет естественных и гуманитарных наук в г. Седльце, Польша, 08-110, Седльце, ул. Жутня, 39; katarzyna.maksymiuk@uph.edu.pl

This research was supported by the Ministry of Science and Higher Education of Poland (grant No. 107/20/B). We would like to thank all the anonymous reviewers and Jowita Buńko for correcting the text.

Статья подготовлена при поддержке гранта № 107/20/В Министерства науки и высшего образования Польши. Мы хотели бы поблагодарить всех анонимных рецензентов и Йовиту Бунько за исправление текста.

(c) St. Petersburg State University, 2021 


\section{Изображение воина на золотых застежках из Тилля-тепе}

\section{П. Скупневич, К. Максимюк}

Для цитирования: Skupniewicz P., Maksymiuk K. The Warrior on Claps from Tillya Tepe // Вестник Санкт-Петербургского университета. История. 2021. Т.66. Вып. 2. С. 567-584.

https://doi.org/10.21638/11701/spbu02.2021.215

Среди предметов, раскопанных в 1978 г. на городище Тилля-тепе (Северный Афганистан) советско-афганской археологической экспедицией под руководством В. И. Сарианиди, особое внимание военного историка или исследователя древнего оружия и доспехов привлекают двойные золотые застежки из захоронения III. Личность персонажа на пряжках Тилля-тепе изучалась довольно редко. Ученых обычно устраивает общий термин «воин». Казим Абдуллаев идентифицировал его как Ареса-Александра. Жаннин Дэвис-Кимбалл определила его как Энари, кастрированного жреца одного из прозрений Великой Богини. Патрик Скупневич был согласен с ее версией, связывая персонажей из пряжек Тилля-тепе с северной индийской, в основном гандхарской, иконографией Сканда Картикеи, который, будучи богом войны, являлся индийским эквивалентом Ареса. В статье обнаруживается соответствие изображений на разных пряжках Тилля-тепе богинь, которые довольно часто встречаются в иконографии, связанной с обсуждаемыми застежками. Вооруженная и восседающая на троне богиня была идентифицирована как иранская богиня Арштат на кушанских монетах. Воина, изображенного на золотых пряжках из Тилля-тепе, следует интерпретировать как изображение Арштата, образ которого был заимствован из иконографии Афины. Богиня изображена сидящей на троне с ногами в форме грифона, известного уже во времена Ахеменидов, в позе, разработанной художниками в поздний эллинистический период. Ключевые слова: Тилля-тепе, Средняя Азия, оружие и доспехи, Александр Македонский, Арштат, Энари.

\section{Introduction}

Among the objects excavated by the Soviet-Afghan archaeological expedition led by Victor Sarianidi on the site of Tillya Tepe in Northern Afghanistan in 1978 ${ }^{1}$, the golden clasps from Burial III [no. 04.40.245], owing to their distinct Hellenistic nature, are of special importance to any military historian or researcher in the area of ancient arms and armor (Fig. 1). The center of the clasps, consisting of two openwork rectangles provided with two hook-and-loop fasteners, is occupied by representations of two, almost identical, armed personages in the Hellenistic military garb. Added to other military artefacts found in Tillya Tepe, influenced by both Hellenic and Kushan cultures, they give us knowledge necessary to reconstruct the panoply of elite soldiers of Hellenistic Bactria and the polities which came into being after its fall. Many of the artefacts have already been examined, which revealed their specific character as products of blending of Hellenistic, Steppe, Parthian Iranian and even Chinese cultures, both as direct imports or products of eclectic application of different motifs. However, this fascinating diffusion of different elements and motifs being caught in the process of transfer from one stylization to another, causes

${ }^{1}$ Sarianidi V.: 1) The golden hoard of Bactria: from the Tillya-tepe excavations in northern Afghanistan. New York; Leningrad, 1985; 2) Khram i nekropol' Tillya-tepe. Moscow, 1987. - The objects from Tillya-tepe belong to the collection of the National Museum of Afghanistan, Kabul. 


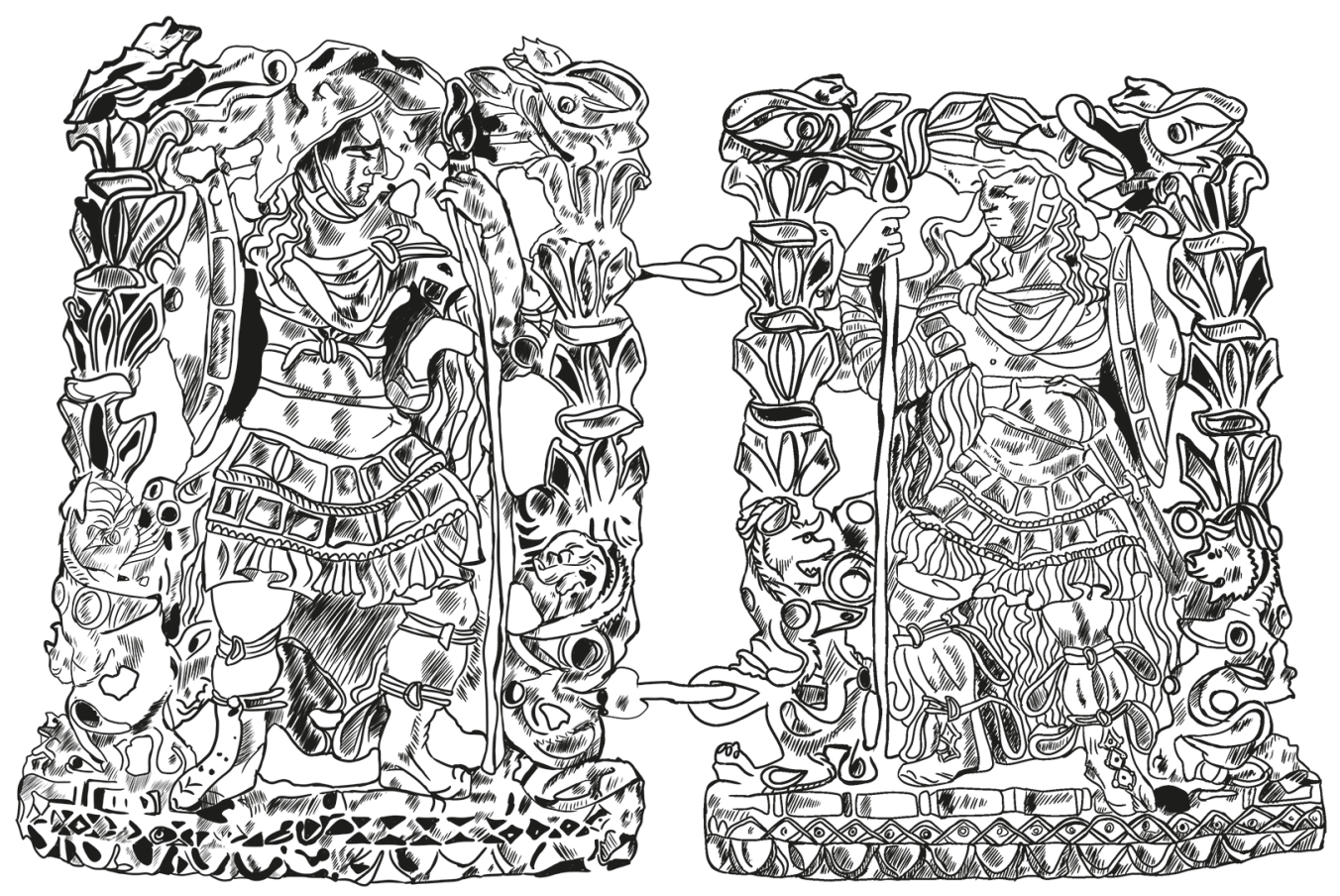

Fig. 1. The golden clasps from Burial III (drawing by E. Skupniewicz)

difficulties in interpretation ${ }^{2}$. Such was the case of the golden clasps from Burial III, where the identity of the depicted personages, despite several attempts to identify them made by different scholars, remains obscure. This article puts forward a hypothesis solving this intriguing puzzle.

\section{Description of the golden clasps from Tillya Tepe}

The golden clasps from Tillya Tepe are two, openwork, symmetrical, vertically-positioned rectangles measuring $9,0 \times 6,3 \mathrm{~cm}$, made in the process of soldering thin pieces of golden foil with the effect of convex shapes becoming visible on the obverse of the object. In the center of each element an armed personage is placed with their head turned towards the axis of the object (where the interlocking parts of the device are attached) so that the personage on the left looks right and the one on the right looks left (facing each

2 The burials belonged probably to Yuezhi-Kushans or to early Kushans, see: Sarianidi V.: 1) The Treasure of Golden Hill // American Journal of Archaeology. 1980. Vol. 84, no. 2. P. 125-131; 2) Tilya Tepe: The Burial of a Noble Warrior // Persica. 1990-1992. Vol.14. P. 103-130; Boardman J. The Tillya Tepe Gold: a closer look // Ancient West and East. 2003. Vol.2. P. 349; Boardman J. The Greeks in Asia. London, 2015. P. 208-220; identifying the site as belonged to the Sakas, see: Pugachenkova G.A., Rempel L.I. Gold from Tillia-tepe // Bulletin of the Asia Institute. 1991. Vol.5. P.11-25; on an association between Tillya Tepe and Parthia, see: Olbrycht M. Archaeological Discoveries at Tillya-tepe and Parthia's Relations with Bactria // Parthica. 2016. Vol. 18. P.9-30; Shenkar M. The Headdress of the Tillya Tepe "Prince" // Ancient Civilizations from Scythia to Siberia. 2017. Vol.23. P. 151-183; discussion with literature in Francfort H.-P. Tillya Tepe and connections with the Eurasian steppes // Afghanistan: Forging Civilizations along the Silk Road. New York, 2012. P. 88-101. 
other). The personages' torsos are straight. Standing alongside the inner edges of the twin clasps each personage rests one of their hands (right/left one) on the shaft of a short spear, while the other hand holds a round, convex shield resembling a lens, bordered with a row of elongated rectangles, seen in profile. The sleeves of the spear-wielding arms are densely scaled. Both legs of each personage are bent, and one of the knees (the one next to the spear) is turned towards the inner edge of the clasp, while the other one is turned towards the viewer. The personages wear a muscle thorax bordered with a double-row pteryges reaching their knees, and a chlamys pinned on one of the shoulders (right/left one) with some kind of a fastener. There is also a fragment of another pteryges used to protect the warrior's arm (of which only one is visible on each figure while the other is covered by the cloak) The personages do not have any facial hair. They have large, slightly hooked noses, large, almond-shaped eyes, and thick, fleshy lips. Each of them wears a Boeotian helmet with its end covering the forehead in the form of a beak. The helmet is supplied with two cheek-pieces i.e. a rectangular part covering the upper cheek and a triangular one reaching the jaw. On the body of the helmet, over the temples, there are some upward-directed, almond-shaped, side ornaments. From the top of the helmet an elongated, serpent-like shape protrudes, forming a loop over the personage's head and fluttering like a ribbon over the spear-holding arm. The personages' long hair falls on their shoulders from under the helmet. Their chests are covered with breastplates fastened with a knot at the height of the solar plexus. A sheathed sword with a pommel in the shape of a bird of prey hangs from a belt placed somehow diagonally over the hip. It is held in the scabbard-slide fastened to the belt on the left side of the hip, being fully visible on the right clasp, while on the left one only its handle can be seen. The personages wear boots bordered with some kind of stripes, tied in a knot, with loops hanging around the personages' calves. Such loop-ending stripes are likewise attached to the legs in the area just below the personages' knees. There is a gem in the center of each stripe-binding. The stripes were probably decorative pieces or were used to fix baggy trousers.

The personages are flanked on both sides by ornamental margins, the bottom parts of which are made of S-shaped, twisted figures of lion-headed griffins, each of them standing on a large lion's paw, looking towards the center of the scene and reaching the personages' thighs. Above the feline heads of the griffins there are four segments of columns resembling fleur de lis or some simplified lotus flowers. The columns are crowned with figures of birds of prey facing the scene (turning towards the central axis of each of the clasps), holding a ribbon in their beaks. There is a horizontal bar made of fleur-de-lis ornaments, a part of which is hidden behind the personages' heads, running between the birds and closing the composition on the top.

There is another horizontal bar running across the scene at the height of the griffins' heads and the personages' thighs. Its thickness and solid structure contrasts with the seamless, almost invisible connections between the warriors' arms and shields and the vertical frame bars.

The clasps have two separate bottoms extending slightly beyond the vertical frames of the pieces. They consist of three ornamental layers: the first one is covered with a row of small, horizontal rectangles; the second one - with a row of convex rhombuses with a single dot in the middle; and the third, lowermost layer — with some simplified cymatium. 


\section{Discussion}

The 'frame'. The frames encircling the personages have so far been called 'columns' or 'trees'. Since they have been identified as purely ornamental forms closing the composition, no further attention has been devoted to them by scholars ${ }^{3}$, whereas understanding their function may enable to decipher the clue and lead to the re-interpretation of the depicted personages. Many clasps which have been excavated in Tillya Tepe do not have such a decorative finish, for example, the golden clasps from Burial III depicting putti riding on dolphins [no. 04.40.110]; the clasps from Burial VI depicting the Triumph of Dionysus' [no. 04.40.53] ${ }^{4}$; or the golden relief figurines depicting winged, semi-nude, female figures or 'Heavenly Aphrodite' [no. 04.40.109] from Burial II. This suggests that decorative frames were not purely aesthetic elements of Tillya Tepe clasps and figurines, so the uncharacteristic finish of this particular format was probably more than a stylistic measure or an ornament. The only other pieces of jewelry found in Tillya Tepe with the central depiction being surrounded by an abstract, geometric square, are the temple pendants from Grave VI portraying the semi-nude, (probably) winged, Heavenly Aphrodite as potnia theron, 'between two monsters', or the round shoe buckles visible in the depiction of the so-called 'Chinese' chariot [no. 04.40.383], and the plaques on the golden plate depicting a personage riding on a feline from Grave IV [no. 04.40.384] (however the format and the function of the items have not been examined yet). Thus, it was not conventional practice for Tillya Tepe goldsmiths to frame the formats of the jewelry pieces they manufactured, although it was not an offence against decorum likewise. It is difficult to determine the detailed chronology and the origin of the artefacts; however, since they were found on the same archeological site and are stylistically related, it is safe to assume that their manufacturers followed the same aesthetic principles.

The frames of the temple pendants from Grave VI resemble architectural elements of a shrine or a temple, enabling scholars to locate the depiction in its proper semantic context. The sides of the pendants are encircled by columns or pillars founded on a turtle's back or the heads of some beaked monsters, with birds of prey sitting on their tops. Placed on top of the columns/pillars is a roof or a canopy, crowned with a rosette. These almost undecorated frames differ from the lavishly decorated borders of the clasps from Grave III. Moreover, the temple pendants have a number of golden discs attached to them, dangling freely on the chains, so that their reinforced frames perform an additional, constructional function, providing also a place for the loops (of the loops-and-hooks mechanism). The frames of the 'warrior' clasps in question also have anchor points for the hooks-and-loops device, however, as can be observed in other Tillya Tepe artefacts, it is possible to solve this technical problem in a different way (so that any allegedly-meaningless, pseudo-architectural elements are not required). It is therefore plausible that the frames of the 'warrior' clasps were deliberately added, which render them not purely ornamental frames, but immanent and meaningful elements important for understanding of the depiction.

The S-shaped body of a lion-griffin with its head turned towards the center of the scene and its small, stylized, comma-shaped wings standing on a single lion's paw, occu-

${ }^{3}$ Francfort H.-P. Tillya Tépa (Afghanistan). La sépulture d'un roi anonyme de la Bactriane du Ier siècle p. C. // Topoi Orient Occident. 2011. Vol. 17 (1). P. 292-295.

${ }^{4}$ Boardman J. Tillya Tepe: echoes of Greece and China // Afghanistan: Forging Civilizations along the Silk Road. New York, 2012. P. 105-106. 
pies a third of the length of the 'base' of the alleged side 'columns' or 'trees'. The lion-griffin motif was frequently used in the production of griffin-legged thrones during the later Sasanian bronze era, examples of which are available in the Hermitage [no. S250]; the Israel Museum in Jerusalem [no. 2002.110.0077]; the British Museum [no. 124093]; and the Metropolitan Museum of Art [no. 1971.143]. The throne with its legs in the shape of the paw of a lion carrying a column crowned with a horned griffin dates back to the Achaemenid era, an example being the throne platform attested on the funerary relief of Darius I in Naqsh-e Rostam (Iran) ${ }^{5}$. A horned, winged, four-legged lion-griffin cast in bronze, which was probably a throne leg, is available in the British Museum [no. WAA 123267]. A bronze throne leg found in the vicinity of Samaria, identical to the legs visible in the Achaemenid reliefs in Persepolis ${ }^{6}$, is now in the Israel Museum [no. 70.92.612; no. 69.8.428] ${ }^{7}$.

Thrones supported by griffins or other fantastic hybrids are depicted in the Parthian relief with enthroned Artabanus from Susa, kept in Iran Bastan Museum ${ }^{8}$; the Kushano-Sasanian silver plate from Rawalpindi, now in the British Museum [no. 124093]; the silver plate from Strelka, now in the Hermitage (winged horses) [no. S250]; the glass and gold vessel in the Bilbliotheque Nationale (winged horses) [no. 379]; the silver plate from Qavzin, now in Iran Bastan Museum (lions) [no. 904]; and the silver bowl from Iran or Afghanistan, now in the Hermitage (lions) [no. S-499] ${ }^{9}$. Birds of prey are shown as figurative throne legs on the silver bowl from the Walters Art Gallery [no. 57.625]. The Parthian king is depicted reclining on a coach supported by birds of prey on the Tang-e Sarvak relief ${ }^{10}$. Figurative throne legs are also shown in Hatra, Dura Europos, Palmyra, and painted on the Penjikent murals.

The popularity of the 'lion-legged chair' and the 'sphinx throne', as Herrmann named these decorative pieces of furniture, dates back to the pre-Acheamenid period and has continued through the Hellenistic and Roman periods in the West until modern times. As Herrmann clearly explains, the sphinx throne became popular among Phoenician artisans and "has maintained its popularity through 3000 years and is still in use today"11. Thus, the popularity of the prestigious, luxury chairs in the Post-Hellenistic Bactria and later in Iran is therefore natural.

Figurative throne legs (lion's paws) are depicted on the gold coin of the Kushan ruler Huvishka [BM 1894,0506.46]. However, it must be pointed out that except for decorative furniture elements griffins with a single paw were not part of Iranian and Central-Asian ancient imagery. Although serpentine beasts frequently appear in the art of the Sakas, inhabitants of the Great Steppe, and the Chinese art of Han Dynasty, they are never shown standing on a single feline's paw.

${ }^{5}$ Schmidt E. Persepolis III: The Royal Tombs and Other Monuments. Chicago, 1970. Pl. 19.22A. 25.

${ }^{6}$ Schmidt E. Persepolis I: Structures, Reliefs, Inscriptions. Chicago, 1953. Pl. 108-111, 121-123.

7 Tadmor M. Fragments of an Achaemenid Throne from Samaria // Israel Exploration Journal. 1974. Vol.24, no. 1. P.37-43. See also: Kidd F. Complex Connections: Figurative Art from Akchakhan-Kala and the Problematic Question of Relations between Khorezm and Parthia // Topoi Orient Occident. 2011. Vol. 17 (1). P. 249-252.

8 Ghirshman R. Persian Art: The Parthian and Sassanian Dynasties, 249 B. C.-A. D. 651. New York, 1962. P. 56, Fig. 70.

9 Harper P. O. Thrones and Enthronement Scenes in Sasanian Art // Iran. 1979. Vol. 17. P. 49-64.

10 Ghirshman R. Persian Art. P. 54, Fig. 67.

11 Herrmann G. Ancient Ivory: Masterpieces of the Assyrian Empire. New York, 2017. P. 160-168 (esp. P. 168). 
The lion-griffin element of the golden clasps from Grave III reaches slightly above the personage's knees marking the point where a horizontal bar behind the personage's thighs is attached. However, the bar is not a structural piece connecting the warrior to the frame to strengthen the structure. Attaching the figure of the warrior (or their equipment) to the frame did not require any additional, in-between elements and was not a technical problem to the goldsmith, as was clearly visible in the case of the 'seamless' tangent points connecting the spear-head, the arm, the head and the shield to the frame. Thus, inserting the horizontal bar as a connecting element to strengthen the structure was unnecessary, especially as it was impossible to hide it from the viewer (which was not, in fact, what the artisan intended to do). On the contrary, the goldsmith not only attached the bars there, but also decorated the bar on the right clasp with three circles, making it even more visible to the viewer. This, combined with the fact that lion-griffins were popular furniture motifs, leads to the conclusion that the horizontal bar can be nothing but a throne seat.

The almost square element behind the personage's head and torso, made of segments resembling fleur-de-lis or a simplified lotus flower must, therefore, represent the high back of the thronos, a type of throne used in the Achaemenid and Parthian periods, which is also well-attested in Hellenistic iconography in both the Seleucid kingdom and Bactria. Francfort's suggestion that this space is occupied by stylized trees ${ }^{12}$ must be refuted as this stylization is in disagreement with the realistic style of the clasps and the general style of Tillya Tepe objects. It is also in disagreement with the way trees were commonly depicted in Central Asian and Iranian ancient art, examples of which are provided by Francfort in his article. Thus, the only interpretation of the object occupying the space in question is that it is a construction element of the throne, i. e. its back.

Birds placed on top of the frames encircling the throne are reminiscent of the depictions of enthroned goddesses of Hariti type sculpted on the Gandharan roundels or phalerae assembled in the al-Sabah Collection [no. LNS 1318.M, no.LNS 1319.M], the Metropolitan Museum [no. 1981.460.2] and the Ashmolean Museum [no. EA1997.202]. Bird motifs decorating architectural elements flanking goddesses were generally quite common, good examples being the temple pendants from Tillya Tepe Burial VI [no. 04.40.52], or the bird motif decorating the Parthian terracotta relief representing a goddess worshipped by a noble ${ }^{13}$.

Personage's position. Both personages shown on the clasps are presented in the same way creating symmetrical pictures. The only deviation distorting the almost perfect symmetry is the sword placed on the (same) left hip of both personages (while the shield and the spear are held by the personages' opposite hands). This allowed for some dynamism between the panels to avoid direct symmetry or a twin picture. Symmetrical layouts were typical of clasps and resulted from the function of such objects. However, the designer of the Tillya Tepe clasps did not slavishly follow this tradition, or simply did not want to break the ancient warrior's dress code according to which swords were, as a rule, worn on the left hip (using symmetry elsewhere in the depiction).

The warriors on the Tillya Tepe clasps are most often perceived as walking or standing, which is the first reaction of an observer familiar with realistic depictions based on the principles of geometric perspective. From this point of view, the personages' thighs

12 Francfort H.-P. Représentations d'arbres dans l'art des steppes de l'Asie (du IVe s. av. j.-c. au IIe s. apr. J.-C.) // Larbre en Asie. Paris, 2018. P. 121-147.

13 Rosenfield J. The dynastic arts of the Kushans. Berkeley; Los Angeles, 1967. P. 212. 
are slightly bent, which might result from their energetic pace. However, if we assume that the act of walking is basically moving the body ahead by shifting its weight from one leg to another, it is arguable that bending both legs at the same time is necessary. Also, with both legs bent, the body is balanced backwards, which gives the impression that the personage is standing still rather than moving, de-energizing the whole picture. Interpreting the scene as a war dance, such as the traditional Greek Pyrrihic dance, should be also excluded. Such dances are far more dynamic, as it is visible in the surviving artefacts of Greek art. Additionally, there is not a single example of iconography representing Iranian/ Central Asian war-dances which could serve as a parallel. The spear stuck in the ground and the personages' lubberly squat contrast with anything known as pyrriche ${ }^{14}$.

Apparently, the image of the personages with their torsos turned towards the axis of the clasps is a slightly barbaric, rather unskillful, attempt to show their bodies in contrapposto. Indeed, despite rigid frontalism dominating Parthian iconography, which heavily influenced Tillya Tepe art, depictions of warriors in attempted contrapposto are typical of the art of Gandhara, an example being the Kushan seal with the image of the god MarsAres ${ }^{15}$. However, warriors depicted in this pose typically twist their hips, with one leg bent more than the other one, as in the case of the Kushan coin. This characteristic feature is missing in the scene represented on the Tillya Tepe clasps, and thus, the warriors sculptured there, with both legs bent and hips in the horizontal position, are not in contrapposto pose. The post-Hellenistic artisans in Iran and Central Asia were much more skillful in imitating this pose, and the goldsmiths who made the clasps were part of the artistic elite. The warriors' pose interpreted as contrapposto, war-dance or any other awkward act of walking on both legs bent, is a mistaken conclusion.

Thus, the arguments presented above shed new light on the interpretation of the scene presented on the clasps making it highly plausible that the object embraced by the frames is a form of throne of the post-Hellenistic type, with vivid Achaemenid features, while the position of the personages is a stylization of frontal sitting. With the concept of perspective being still underdeveloped, depicting a personage in the sitting position, shown graphically in front, was a challenge. Consequently, the perspective of the warriors was foreshortened which resulted in the awkward reduction of thighs (and therefore the important area of hips was lost iconographically, while the torso, attached to short legs, became larger), or knees spread wide outside, as it was in the tradition of Sasanian iconography ${ }^{16}$. These difficulties explain why archaic and classical Greek graphic artists were probably unwilling to show enthroned or seated personages frontally ${ }^{17}$. Examples of this kind are few and far between. One of them is the enthroned goddess shown frontally on the Scythian gold rhyton from Merdzhana [Hermitage, no.2521-10], or the diadem

${ }^{14}$ About the armed dance, see: D'Agata A.L. The power of images. A figured krater from Thronos Kephala (ancient Sybrita) and the process of polis formation in Early Iron Age Crete // Studi Micenei ed Egeo-Anatolici. 2012. Vol. 54. P. 232-236.

15 Skupniewicz P. Some Remarks on the Elements of Infantry Protective Gear in Art of Gandhara: An Evidence for Survival of Hellenistic Military Tradition? // Metamorphoses of History. 2016. Vol. 7. P. 39-66.

16 E. g. Relief from the small cave at Taq-e Bostan (Iran) (Fukai Sh., Sugiyama J., Kimata K., Tanabe K. Taq-i-Bustan: III - Photogrammetric Elevations // The Tokyo University Iraq-Iran Archaeological Expedition Report 19. Tokyo, 1983. Pl. XXII-XXIV; silver plate from Iran Bastan Museum [no. 904]; glass and gold vessel in Bilbliotheque Nationale [no. 379]).

17 There are examples of frontally seated personages in red-figure painting but they should be qualified as exceptions and do not concern personages of high status. 
from Karagodeuashkh [Hermitage, no. 2492-7]. Interestingly, in the case of the enthroned female deity on the Sakhnovka diadem only her face is shown frontally, while the rest of the body is shown in profile [the Museum of Historical Treasures of Ukraine, no. 1639]. Also, the goddess on the decorations from Chertomlyk is shown in profile [the Hermitage, по. Дн.1863-1/374a].

Showing the profile of enthroned figures in the sitting position was popular in Achaemenid iconograph. This practice survived in the Parthian system of coinage [BM 1881,0504.7; BM 1891,0603.6]. One of its limitations was the inability of the dramatis personae to address the viewer, resulting in his/her externalization (as the scene was closed, only the internal elements could interact, and the spectator was not invited to the scene). However, this effect did not interfere with the narrative function of art, i. e. to document an event (without allowing the audience to be directly involved, though). Without direct interaction between the audience and the subject, the impact of art was limited as far as the depiction of rituals or exploits was concerned. In order to invigorate images of enthroned personages depicted in profile, figures were shown in more dynamic poses such as standing and stretching one hand and one leg, while the other leg was bent. Occasionally, the rigid profile was eased by the personage's torso shown frontally and both legs foreshortened, approximating to en trois quarts, as it is evident on the ivory reliefs from Demetrias depicting a Persian king or a satrap ${ }^{18}$. Some attempts to show personages sitting on the high back thronos in the frontal pose were made on the reverse of coins minted by eastern-Hellenistic coiners, who adopted the frontal view of the model's head and torso, while foreshortening the seat and the legs from a three-quarters angle. The thighs were positioned somehow diagonally, while the shins were bent - the left one most often at an acute-angle, and the right one - at an obtuse angle, which was in line with the formerly developed practice of showing enthroned personages in a more dynamic manner. The formula of depicting seated deities frontally with their legs turned in one direction on the reverse of the coins was applied both to male (Zeus) [BM 1853,0616.6; BM 1949,0411.275] and female deities (Athena) [BM 1919,0820.1], and outlived Greek polities, becoming also popular in the Indo-Scythian system of coinage [BM 1976,1006.20].

In the monumental art of the Parthian period in Iran, the heads and torsos of enthroned figures and the back of the thrones were depicted frontally, while the legs and the seat were foreshortened in three quarters, as can be seen on the relief of Artabanus from Susa representing a reclining figure from Tang-e Sarvak, and the bullae from Gobekly Tepe $^{19}$. Depictions of enthroned personages were also sculptured on the reverse of coins minted during the reign of Kujula Kadphises and the Kushano-Sasanian king Ohrmazd I ${ }^{20}$. In contrast to the Eastern-Hellenistic or post-Hellenistic art, here the legs were positioned almost parallel to the axis of the torso. The practice of depicting models in the frontal sitting position with their knees directed to the sides developed in the Kushan coinage and dominated the imagery of enthronement in the Sasanian era, one example of this practice being the Parthian bone plaque found in $\mathrm{Olbia}^{21}$ showing the enthroned ruler in the

18 Boardman J. Persia and the West. London, 2000. P. 199.

19 Koshelenko G., Gaibov V., Bader A. Dve bogini? // Vestnik Drevnei Istorii. 1995. Vol. 2. P. 194-203.

20 Shenkar M. Intangible Spirits and Graven Images: The Iconography of Deities in the Pre-Islamic Iranian World. Leiden; Boston, 2014. P. 372.

${ }^{21}$ Kaim B. Bone Reliefs from Fire Temple at Mele Hairam, South-West Turkmenistan // Iranica Antiqua. 2010. Vol. 45. P.334, Pl. 3. 
full-frontal pose with knees directed to the sides. It is possible that the tradition of rulers sitting on low thrones with their knees out originated in the nomadic era when men used to sit on the ground with their legs crossed, examples of such positions being evident on the decoration of Kobyakovo diadem ${ }^{22}$, the coins of Indo-Scythian kings [BM IOLC. 828] and the coins of Kujula Kadphises [BM 1922,0213.59]. Leaders were also depicted sitting on a decorated, folded, metal stool, which was attested for the first time on the Khalchayan reliefs $^{23}$. showing distinctive personages sitting on low thrones with their knees directed aside. Another example of this kind is the gold coins of Vima Kadphises, where the emperor is shown either with legs crossed [BM 1894,0506.2], or sitting frontally on a low throne with legs aside [BM IOC. 268], and Manaobago, the deity of the Kushan pantheon, who is always shown frontally when depicted enthroned [BM 1894,0506.46]. Depictions of female deities sitting frontally are also common in the Kushan and Kushano-Sasanian coinage [BM 1892,0202.3], such as the Sogdian religious iconography, and the Gandharan art of the Kushan era. However, since these high reliefs are nearly three dimensional, they can serve as examples of frontal positions only. Additionally, the figurines from Payenkurgan of the Kushan era show female deities frontally, without directing their knees out, though ${ }^{24}$. Clearly, all the three models of representation of enthroned figures were part of Kushan imagery. This leads to the conclusion that it was the Kushan milieu which made Parthian artisans abandon the former tradition of depicting enthroned rulers according to the Hellenistic tradition in favor of the fully frontal representation, originating, probably, in nomadic practices. It was, however, a long-lasting process, and the new model was probably in use parallel to the old one until the Sasanian era.

The transition between the three-quarter pose and the frontal model can be observed on the Kushano-Sasanian plate from Rawalpindi (mentioned earlier in the article), available in the British Museum. Depicted in the center of the plate is a clearly male figure, sitting on a griffin-legged throne in the typical Kushano-Sasanian way, while the personage below is shown in a position approximating to en trois quarts. It is interesting that female personages are shown in poses being a combination of the frontal and three-quarter positions, while male ones are shown either in the frontal pose, sitting with their knees directed outside (or crossed), or reclining. The poses of the personages depicted on the Tillya Tepe clasps indicate that they were in the sitting position i.e. seated on the thrones. Showing a person sitting with one leg bent towards the viewer and the other slightly aside was a characteristic feature of stylization of such positions observable on the reverse of coins of the late Hellenistic and post-Hellenistic eras. The Tillya Tepe clasps serve as evidence to support the theory of the development of enthronement iconography in Iran and Central Asia and its gradual shift from the strict profile view to direct frontalism, which dominated enthronement scenes in the area until modern times. This ambiguous position of the frontally depicted enthroned personages, typical of this particular stylization, can be also seen on the relief from the Dura Europos temple of Gadde, where the sitting position of Gad (Fortune), the central figure of the relief, installed on the throne, can be easily confused with the standing one [Yale University Art Gallery, no. 1938.5314].

22 Treister M. New Discoveries of Sarmatian Burials of the $1^{\text {st }}$ Century A. D. A Survey of Publications in VDI // Ancient Civilizations from Scythia to Siberia. 1998. Vol. 4, iss. 1. P. 80, Fig. 9.

${ }^{23}$ Pugachenkova G. A. Skulp’tura Khalchayana. Moscow, 1971. Fig. 51.61.

${ }^{24}$ Abdullaev K. K atributsii tronnykh izobrazheniy v kushanskoy koroplastike (po materialam kreposti Payenkurgan v Severnoy Baktrii) // Vestnik Drevnei Istorii. 2000. Vol. 2. P. 20, Fig. 1.1-6. 
Personage's outfit, equipment and face. The central personage wears a muscle cuirass of the Hellenistic type with a double row of pteryges protecting the thighs, and a shoulder protector, which is only fragmentarily seen on their arm. This type of armor is visible on the depictions of Ares (?) on the rhyton from Old Nisa [rhyton no. 30], and on the Kampyr Tepe terracotta slabs ${ }^{25}$. Warriors with laminated arms, wearing muscle cuirasses and leg protectors, being common figures in the Sasanian art, and revealing the Hellenistic tradition in the Iranian cataphract armor, were often represented on the Kushano-Sasanian coins [BM 1989,0904.4001] $]^{26}$.

Short spears held by warriors armed in the Greek style are common on Hellenistic and post-Hellenistic coins from Central Asia. Their round, convex shields appear smaller than the classical Greek hoplite shields. An armor consisting of a spear and a shield described above seems anachronistic in Western Hellenistic states dominated by the sarissa-wielding infantry, and, since $160 \mathrm{BC}$, infantry armed in the Roman style, i.e. using large, oval shields and heavy javelins. However, elements of armor worn by the Greek infantry survived in Central Asia and India, and infiltrated the iconography of warlike deities. The influence of Roman military practices reached Bactria, one example being the Kampyr Tepe terracotta ${ }^{27}$.

The sword with a handle in the shape of an eagle is, with all probability, a makhaira a single-edged, curved, sharp weapon which was in use as far back as the Achaemenid period, and became popular with warriors from Greece and Hellenistic states ${ }^{28}$.

The helmets depicted on the Tillya Tepe clasps are clearly a Hellenistic variety of the 'Boeotian' helmet ${ }^{29}$. However, examples of this kind are not found on coins from Graeco-Barctria. Similar helmets are attested in Hellenistic iconography, the best example being the Sidon stelae [Istanbul Archaeological Museum, no. 1490 T]. Among the objects excavated in Tillya Tepe, a similar helmet, worn by Athena depicted in the standing position, is visible on the pendant excavated on the same burial site (Burial III $)^{30}$. Wide-brimmed helmets, many of them having a triangular beak over the forehead, worn by goddesses of Athena type, replaced the classical Corinthian helmet, a typical element of armor worn by Athena observable on earlier representations of the goddess. Helmets of this type, resembling mediaeval capalines or Renaissance morions but lacking the ridge, can be seen on the heads of female deities in the Gandharan sculpture [Lahore Museum, no. G-132]; the murals from Dilberjin Tepe ${ }^{31}$ (Figs. 2, 3); and also on the Tang-e Sarvak relief and the

${ }^{25}$ Nikonorov V., Savchuk S. New Data on Ancient Bactrian Body-Armour (In the Light of Finds from Kampyr Tepe) // Iran. 1992. Vol.30. P. 49-54.

${ }^{26}$ Mielczarek M. Cataphracti and Clibanarii, Studies on the Heavy Armoured Cavalry of the Ancient World. Lodz, 1993; Abdullaev K. Nomady v iskusstve ellinisticheskoy Baktrii // Vestnik Drevnei Istorii. 1998. Vol.1. P. 87-88; Skupniewicz P. The Iconographic Function of Armor in Sasanian Art // Rivista degli Studi Orientali. Nuova Serie. 2016. Vol. 88. Fasc. 1-4. P. 251-281.

27 Sekunda N. Hellenistic Infantry Reform in the 160's BC. Lodz, 2001. P. 173-176.

${ }^{28}$ Litvinsky B., Pichikyan I. Handles and Ceremonial Scabbards of Greek Swords from the Temple of the Oxus in Northern Bactria // East and West. 1999. Vol. 49. P. 47-104.

${ }^{29}$ Litvinsky B. Khram Oksa v Baktrii (Yuzhnyi Tadzhikistan): v 3 t. T. 2. Moscow, 2001. P. 349-352.

30 Present location unknown. Published by: Sarianidi V. The golden hoard of Bactria... P. 230. No. 78 . Il. 73 .

${ }^{31}$ Kruglikova I. Les fouilles de la mission archéologique soviéto-afghane sur le site gréco-kushan de Dilberdjin en Bactriane // Comptes rendus des séances de l'Académie des Inscriptions et Belles-Lettres. 1977. Vol. 121, no.2. Fig. 11-12; Skupniewicz P., Maksymiuk K. Gordāfarid, Penthesilea and Athena: the identification of a Greek motif in Ferdowsīs Šāh-nāma and its possible association with Hellenistic art in the East // Mediterranean Historical Review. 2019. Vol.34, iss. 2. P. 123-143. 


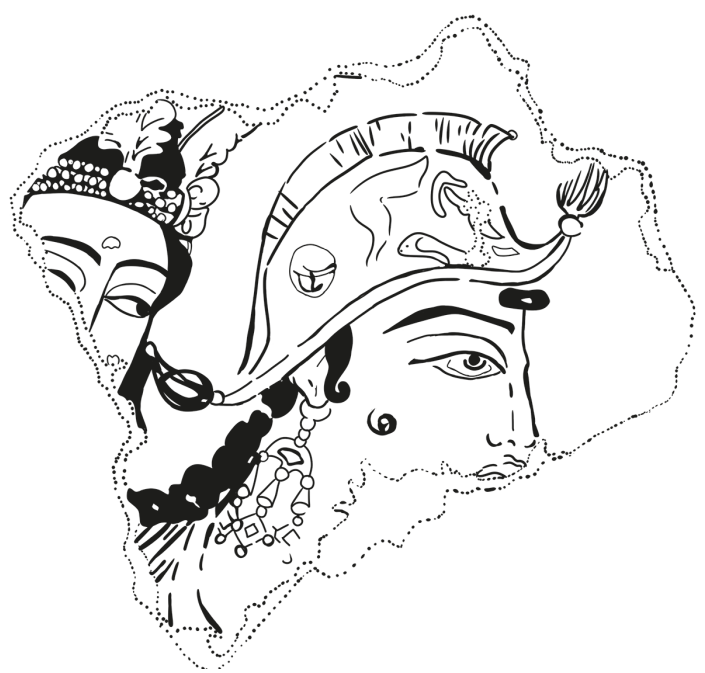

Fig. 2. Athena's head on the murals from Dilberjin Tepe (drawing by E. Skupniewicz)

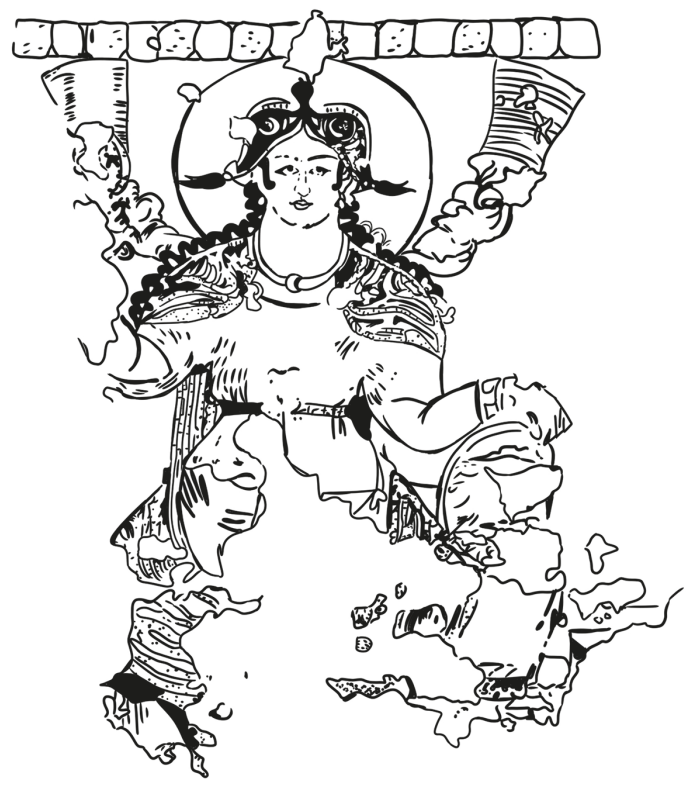

Fig. 3. Athena on the murals from Dilberjin Tepe (drawing by E. Skupniewicz)

Allat sculptures from Hatra ${ }^{32}$. It is possible that the triangular stylization of the front of the helmet was modelled on the classical three-ridged helmet known from iconographic representations of Athena. On the murals from Dilberjin Tepe, helmets of this type are

32 Ghirshman R. Persian Art. P. 92, Fig. 103. 
decorated with three tassels. A triple-plume helmet worn by a personage, who most likely represents a goddess of Athena type, is identified on the Kuh-e Khwaja mural ${ }^{33}$. The structure of this helmet, which seems to be a simple hemispherical headgear, has not been fully explained due to the fact that the mural has only fragmentarily survived.

The three small tassels attached to the helmets worn by the goddesses from Dalverzin Tepe ${ }^{34}$ are reminiscent of the small, almond-shaped protrusions on the helmet on the Tillya Tepe clasps. However, only two such protrusions are attached to the sides of the helmet, and the forehead is decorated with an element resembling a plume or horse's ears.

Since they do not have any beards, it is difficult to determine the sex of the personages. Their large, almond-shaped eyes and pronounced noses are reminiscent of the face of Alexander the Great depicted on the mosaic from the House of Faun in Pompeii ${ }^{35}$. However, they could be also elements of the face of the goddess from Dilberjin Tepe. Images of heads of men wearing helmets, depicted with hair falling on the shoulders, are not characteristic of the Hellenistic and post-Hellenistic art. Similarly, Alexander the Great was not represented with such long hair in any of his portraits, while goddesses of Athena type were frequently depicted with their locks falling from under their protective headgears. The only male personage with long hair is the long-haired Verethraghna who occasionally appears on the reverse of Kushan coins; however, he is never shown wearing a helmet and an armor.

\section{Conclusion}

Scholars have not expressed much interest in the problem of identity of the personages depicted on the Tillya Tepe clasps, and most of them are satisfied with the generic term 'warrior' ${ }^{36}$. One of those who examined the problem in more detail is K. Abdullaev who identified the personages as Ares-Alexander, observing some similarity between their faces and the iconographic representations of Alexander the Great, illustrating his idea by the examples of figures of Ares from Old Nisa and the Kushan seal ${ }^{37}$. Initially, P. Skupniewicz accepted Abdullaev's theory (at least, to some extent) recognizing the personages in question as the war-god Skanda Kartikeya, an Indian equivalent of Ares, typical of the North Indian iconography, mainly of the Gandhara region ${ }^{38}$. However, more thorough examination revealed the major drawback of this theory as it ignored the fact that the personages

${ }^{33}$ Kawami T. S. Kuh-e Khwaja, Iran, and Its Wall Paintings: The Records of Ernst Herzfeld // Metropolitan Museum Journal. 1987. Vol.22. P.35, Fig. 14.

${ }^{34}$ Pugachenkova G. A. Les Trésors de Dalverzine-Tépé. Leningrad, 1978. Fig. 52. 53.

35 Abdullaev K. Aleksandr-Ares v Baktrii (K voprosu ob identifikatsii obraza voina iz Tillyatepa) // Vestnik Drevnei Istorii. 2016. Vol.76, no.3. P. 588; Dubbini G. From Northern Afghanistan to Xinjiang, Hellenistic influences in the history of a Yuezhi-Kushan burial // Journal of Asian Civilizations. 2014. Vol. 37, no. 1. P. 13-14.

${ }^{36}$ Boardman J. Tillya Tepe: echoes of Greece and China. P. 108; Schiltz V. Tillya Tepe, the Hill of Gold: a Nomad Necropolis // Afghanistan: Crossroads of the Ancient World. London, 2011. P.254. - Warrior or king (perhaps deified) see: Francfort H.-P. Tillya Tépa (Afghanistan). P. 292-295.

37 Abdullaev K. Armour of ancient Bactria // In the Land of the Gryphons: Papers on Central Asian archaeology in antiquity. Firenze, 1995. P. 168; Abdullaev K. Aleksandr-Ares v Baktrii... P. 579-596; Abdullaev K. The Image of Alexander the Great in Small-Form Art in Bactria (and Identification of the Depiction of a Warrior on the Gold Clasp from Tillya Tepe) // Ancient West \& East. 2017. Vol. 16. P. 155-175.

38 Skupniewicz P. Bóg Skanda-Kartikeia w ikonografii Gandhary // İstoriâ relìgij v Ukraïnì: naukovij sorì̌nik. 2017. Vol.27.2. P.95-103. 
are seated on thrones. There are not any depictions of enthroned Ares wearing an armor (armored Ares is shown in the standing position). Then, representation of Ares wearing a helmet, geographically and chronologically related to Tillya Tepe, are different from those on the 'warrior' clasps. Another argument against Abdullaev's theory is that Hellenistic warriors are not depicted with their hair falling on the shoulders. It cannot be denied that Alexander's hair is not short, as can be seen on the Pompeian mosaic; however, it is not as long as the hair of the personages on the clasps. Then, the alleged facial similarity between the personages on the clasps and Alexander the Great is lacking in objectivity: the resemblance is more evident in the case of the warrior on the left-side clasp, while facial characteristics of the warrior on the right-side clasp are typical of a female face as it is represented in Indian art. Finally, the image of enthroned Ares wearing a Boeotian helmet, with his hair falling on the shoulders, in unattested in iconography.

Davis-Kimball identified the personages as Enaree, the castrated priest of one of the epiphanies of the Great Goddess ${ }^{39}$. This identification is based on the author's assumption that women played an important role and had a strong military position in the nomadic societies of the Great Steppe, which is not, however, illustrated by any iconographic examples (not a single iconographic representation of Enares is known to scholars), and thus, is only a pure speculation. The mere fact that the clasps were found in a grave of a high-status woman, who had a dagger in her grave inventory, does not prove that the beardless personage depicted on the clasps is a eunuch-warrior. Since it has not been documented that Enares performed any military functions, and the iconographic piece Davis-Kimball examined was not compared to any relevant work of art, Davis-Kimball's theory is still a conjecture rather than a fact.

There is a similar parallel between the Tillya Tepe clasps and depictions of goddesses of Athena type, stemming from iconographic borrowings from Greek art to Asia, where enthroned, helmeted female personages were depicted holding a spear and a shield, although the Greek model was not followed slavishly. Manifestations of iconographic independence are clearly visible in the way Athena is represented in Asian art, i.e. seated on the throne wearing a helmet and holding a shield in one hand and a spear in the other one (Dalverzin Tepe). When depicted in the standing position, she is shown with her shield on the ground or supported by her left hand, while her right hand rests on the spear-shaft. Alternatively, sometimes her right arm is extended carrying Nike or in a gesture of blessing. Although the standing (Fig. 4) or sitting (Fig. 5) position of Athena, with her left hand resting on the shield placed upright on the ground, is quite common, the sitting position, with a shield on the shoulder and in an armor, is also attested, examples being the gem from Burial II in Tillya Tepe [no. 04.40.117]; the jet stone seal from a private collection ${ }^{40}$; the statue of Allat from Palmyra ${ }^{41}$. It is even more popular among goddesses in the standing position represented on the pendant from Burial III in Tillya Tepe (the same burial

${ }^{39}$ Davis-Kimball J. Enarees and Women of High Status: Evidence of Ritual at Tillya Tepe (Northern Afghanistan) // Kurgans, Ritual Sites, and Settlements: Eurasian Bronze and Iron Age. Oxford, 2000. P. 223-229.

40 Private collection, London. See: Stančo L. Greek Gods in the East: Hellenistic Iconographic Schemes in Central Asia. Prague, 2012. P.57, Fig. 47.

41 Gawlikowski M. The Athena of Palmyra // Archeologia. 1996. Vol.21-22. P.21-32. 


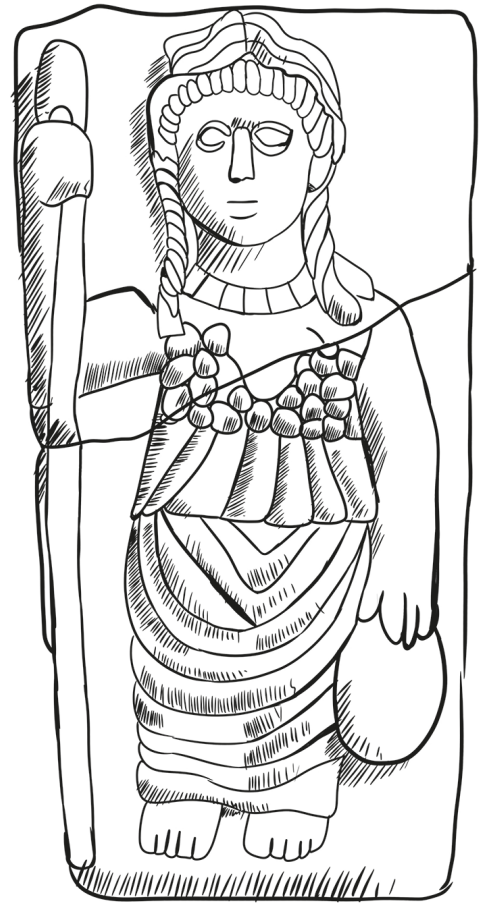

Fig. 4. Athena from Hauran, area of Bosra (drawing by E. Skupniewicz)

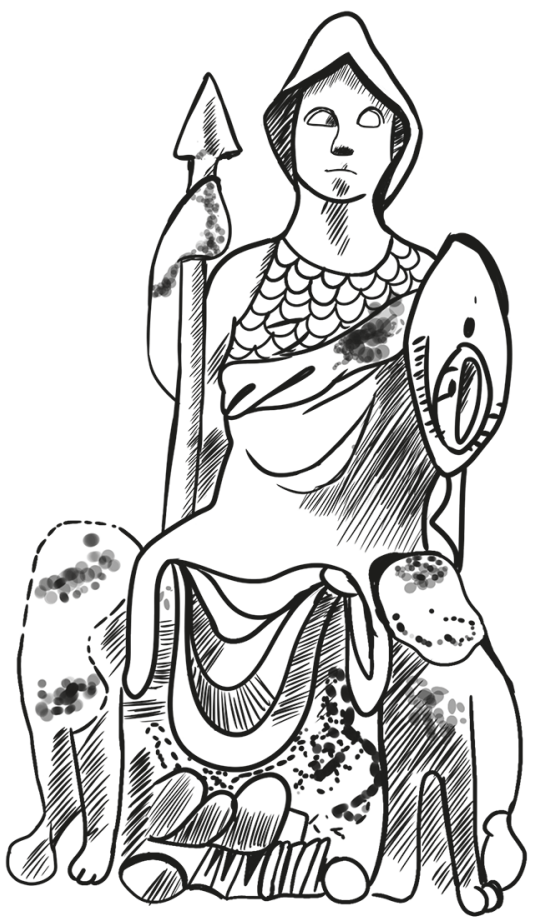

Fig. 5. Athena from Palmyra (drawing by E. Skupniewicz)

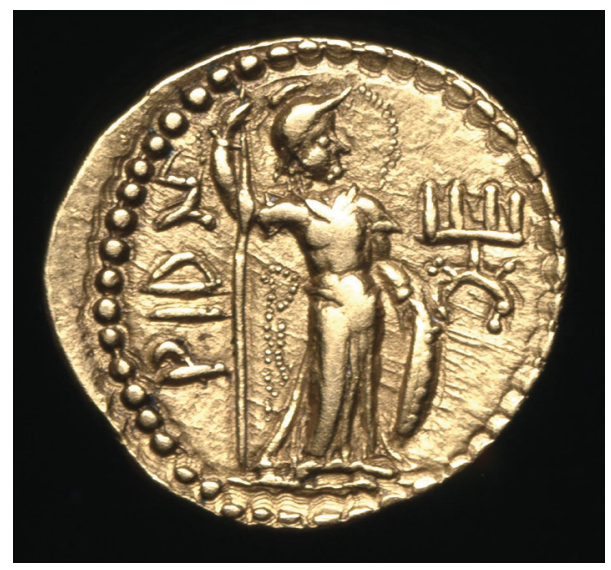

Fig. 6. Arshtat (Risthi) on the coin of Huvishka [Shenkar M., 2014. P. 262]. 
where the 'warrior' clasps were excavated) ${ }^{42}$; the gemstone from Burial V in Tillya Tepe ${ }^{43}$; as well as several other examples attested in east-Hellenistic coinage ${ }^{44}$.

Depictions of enthroned and armed goddesses are quite common in iconography developing in this geographical region at the same time. The armed and enthroned goddess was identified as the Iranian goddess Arshtat (Risthi) represented on Kushan coins [BM 1879,0501.9] (Fig. 6) by Pugachenkova ${ }^{45}$ and Grenet ${ }^{46}$, who examined other pictorial examples of this visual type. This identification was also supported by Shenkar ${ }^{47}$.

The element which might cast doubts on the identity of the personage on the clasps as Arshtat is the cuirass. Although goddesses of Athena type wear helmets and hold shields, and are often shown enthroned and armored, it is, however, possible that Athena's scaled aegis worn to protect her chest and gorgoneion, an apotropaic element decorating lavish breastplates, worn on the scaled surface of aegis, enhanced the interpretation of aegis as an armor, especially in Greater Iran where scaled body protectors were attested in the Achaemenid period and remained in use at least until the Sasanian period. Over time the aegis became a form of honorific armor worn by leaders, kings and gods. It is worth noticing that although representations of armored goddesses are unknown, examples of such representations are attested in literature ${ }^{48}$.

To conclude, the warrior figures depicted on the golden clasps from Grave III in Tillya Tepe should be interpreted as portrayals of the Iranian goddess Arshtat, whose image was brought to Central Asia from the iconography of Athena by Greek-Macedonian. The goddess is seated on a griffin-legged throne, which was in use as far back as the Achaemenid period, in the pose developed in images? in the late Hellenistic period when Tillya Tepe burials were conducted.

\section{References}

Abdullaev K. Nomads in the art of Hellenistic Bactria. Vestnik Drevnei Istorii, 1998, vol. 1, pp. 83-92. (In Russian)

Abdullaev K. Alexander-Ares in Bactria (On the question of identifying the image of a warrior from Tillatep). Vestnik Drevnei Istorii, 2016, vol.76, no.3, pp. 579-596. (In Russian)

\footnotetext{
Il. 73.

${ }^{42}$ Present location unknown. Published by: Sarianidi V. The golden hoard of Bactria... P. 230. No. 78.

${ }^{43}$ Present location unknown. Published by: Ibid. P. 252. No. 1. Il. 102, 103.

44 Stančo L. Greek Gods in the East. P. 53-55, 61.

45 Pugachenkova G. A. Ob odnom ikonograficheskom obraze v iskusstve Baktrii // Vestnik Drevnei Istorii. 1989. No. 4. P. 104-105.

46 Grenet F. L'Athéna de Dil'berdžin // Cultes et monuments religieux dans l'Asie Centrale préislamique. Paris, 1987. P. 41-45. - The icon of Athena was a hellenized synthesis of the two Iranian goddesses Arshtat / Risthi and Ashi / Ardochsho [BM 1894,0506.114; BM 1888,1208.543]. Contra: Kruglikova I. T. Nastennye rospisi Dil'berdzhina // Drevniaia Baktriia. Materialy sovetsko-afganskoi ekspeditsii, 19691973 gg. Moscow, 1976. P. 110; Lo Muzio C. The Dioscuri at Dilberdjin (Northern Afghanistan): Reviewing Their Chronology and Significance // Studia Iranica. 1999. Vol. 28. P. 58. - Interprets a female head wearing a helmet not as Athena-Arshtat, but as Athena-Anahita. This view does not correspond with the inscriptions on the coins. As a matter of fact, the picturing of the female deity in helmet holding a spear and shield must allow for different interpretations, given her popularity in various regions, but the only historical identification at our disposal comes from Kushan numismatics.

47 Shenkar M. Intangible Spirits and Graven Images. P. 87-90.

48 E. g. Herodian V 6.3-4: He [Heliogabal] brought into his own bedroom the statue of Pallas which the Romans worship hidden and unseen... But proclaiming that his god was not pleased by a goddess of war wearing full armor.
} 
Abdullaev K. Armour of ancient Bactria. In the Land of the Gryphons: Papers on Central Asian archaeology in antiquity. Firenze, Le Lettere, 1995, pp. 163-180.

Abdullaev K. The Image of Alexander the Great in Small-Form Art in Bactria (and Identification of the Depiction of a Warrior on the Gold Clasp from Tillya Tepe). Ancient West \& East, 2017, vol. 16, pp. 155175.

Abdullaev K. To the attribution of throne images in Kushan co-plastic (based on the materials of the Paenkurgan fortress in Northern Bactria). Vestnik Drevnei Istorii, 2000, vol. 2, pp. 18-30. (In Russian)

Boardman J. Persia and the West. London, Thames \& Hudson Ltd, 2000, 256 p.

Boardman J. The Greeks in Asia. London, Thames \& Hudson, 2015, 510 p.

Boardman J. The Tillya Tepe Gold: a closer look. Ancient West and East, 2003, vol.2, pp.348-374.

Boardman J. Tillya Tepe: echoes of Greece and China. Afghanistan: Forging Civilizations along the Silk Road. New York, Metropolitan Museum of Art, 2012, pp. 102-111.

D’Agata A. L. The power of images. A figured krater from Thronos Kephala (ancient Sybrita) and the process of polis formation in Early Iron Age Crete. Studi Micenei ed Egeo-Anatolici, 2012, vol.54, pp. 207-247.

Davis-Kimball J. Enarees and Women of High Status Evidence of Ritual at Tillya Tepe (Northern Afghanistan). Kurgans, Ritual Sites, and Settlements: Eurasian Bronze and Iron Age. Oxford, British Archaeological Research Reports, 2000, pp. 223-229.

Dubbini G. From Northern Afghanistan to Xinjiang, Hellenistic influences in the history of a Yuezhi-Kushan burial. Journal of Asian Civilizations, 2014, vol. 37, no. 1, pp. 1-22.

Francfort H.-P. Représentations d'arbres dans l'art des steppes de l'Asie (du IVe s. av. j.-c. au IIe s. apr. J.-C.). Larbre en Asie. Paris, Académie des Inscriptions et Belles-Lettres, 2018, pp. 121-147.

Francfort H.-P. Tillya Tépa (Afghanistan). La sépulture d'un roi anonyme de la Bactriane du Ier siècle p. C. Topoi Orient Occident, 2011, vol. 17 (1), pp. 277-347.

Francfort H.-P. Tillya Tepe and connections with the Eurasian steppes. Afghanistan: Forging Civilizations along the Silk Road. New York, Metropolitan Museum of Art, 2012, pp. 88-101.

Fukai Sh., Sugiyama J., Kimata K., Tanabe K. Taq-i-Bustan: III - Photogrammetric Elevations. The Tokyo University Iraq-Iran Archaeological Expedition Report 19. Tokyo, The Institute of Oriental Culture, The University of Tokyo, 1983, 16 p., 11 pls.

Gawlikowski M. The Athena of Palmyra. Archeologia, 1996, vol.21-22, pp. 21-32.

Ghirshman R. Persian Art: The Parthian and Sassanian Dynasties, 249 B. C. - A. D. 651. New York, Golden Press, 1962, $401 \mathrm{p}$.

Grenet F. L'Athéna de Dil'berdžin. Cultes et monuments religieux dans l'Asie Centrale préislamique. Paris, Éditions du C.N.R.S., 1987, pp.41-45.

Harper P. O. Thrones and Enthronement Scenes in Sasanian Art. Iran, 1979, vol. 17, pp. 49-64.

Herrmann G. Ancient Ivory: Masterpieces of the Assyrian Empire. New York, Thames \& Hudson, 2017, 208 p.

Kaim B. Bone Reliefs from Fire Temple at Mele Hairam, South-West Turkmenistan. Iranica Antiqua, 2010, vol. 45, pp. 321-335.

Kawami T.S. Kuh-e Khwaja, Iran, and Its Wall Paintings: The Records of Ernst Herzfeld. Metropolitan Museum Journal, 1987, vol.22, pp. 13-52.

Kidd F. Complex Connections: Figurative Art from Akchakhan-Kala and the Problematic Question of Relations between Khorezm and Parthia. Topoi Orient Occident, 2011, vol. 17 (1), pp. 229-276.

Koshelenko G., Gaibov V., Bader A. Two goddesses? Vestnik Drevnei Istorii, 1995, vol.2, pp. 194-203. (In Russian)

Kruglikova I. Les fouilles de la mission archéologique soviéto-afghane sur le site gréco-kushan de Dilberdjin en Bactriane. Comptes rendus des séances de l'Académie des Inscriptions et Belles-Lettres, 1977, vol. 121, no. 2, pp. 407-427.

Kruglikova I. Wall paintings of Dilbergin. Drevniaia Baktriia. Materialy Sovetsko-Afganskoi ekspeditsii 1969-1973 gg. Moscow, Nauka Publ., 1976, pp. 87-110. (In Russian)

Litvinsky B. Hellenistic Oaks Temple in Bactria (South Tajikistan). Vol.2: Bactrian armament in the ancient Eastern and Greek context. Moscow, Eastern literature Publ., 2001, 528 p. (In Russian)

Litvinsky B., Pichikyan I. Handles and Ceremonial Scabbards of Greek Swords from the Temple of the Oxus in Northern Bactria. East and West, 1999, vol. 49, pp. 47-104. 
Lo Muzio C. The Dioscuri at Dilberdjin (Northern Afghanistan): Reviewing Their Chronology and Significance. Studia Iranica, 1999, vol.28, pp.41-71.

Mielczarek M. Cataphracti and Clibanarii, Studies on the Heavy Armoured Cavalry of the Ancient World. Lodz, Oficyna Naukowa, 1993, 106 p.

Nikonorov V., Savchuk S. New Data on Ancient Bactrian Body-Armour (In the Light of Finds from Kampyr Tepe). Iran, 1992, vol. 30, pp.49-54.

Olbrycht M. Archaeological Discoveries at Tillya-tepe and Parthia’s Relations with Bactria. Parthica, 2016, vol. 18, pp.9-30.

Pugachenkova G. A. Les Trésors de Dalverzine-Tépé. Leningrad, Éd. d'art Aurore Publ., 1978, 98 p.

Pugachenkova G. A. About one iconographic image in the art of Bactria. Vestnik Drevnei Istorii, 1989, no.4, pp.96-105. (In Russian)

Pugachenkova G. A. Halchayan sculpture. Moscow, Iskusstvo Publ., 1971, 204 p. (In Russian)

Pugachenkova G. A., Rempel L. I. Gold from Tillia-tepe. Bulletin of the Asia Institute, 1991, vol. 5, pp. 11-25.

Reeder E. Scythian Gold. Treasures of Ancient Ukraine. New York, Harry N. Abrams, 1999, 352 p.

Rosenfield J. The dynastic arts of the Kushans. Berkeley, Los Angeles, University of California Press, 1967, $422 \mathrm{p}$.

Sarianidi V. Temple and necropolis of Tillatepe. Moscow, Nauka Publ., 1987, 236 p. (In Russian)

Sarianidi V. The golden hoard of Bactria: from the Tillya-tepe excavations in northern Afghanistan. New York, Leningrad, Aurora Art Publ., 1985, 258 p.

Sarianidi V. The Treasure of Golden Hill. American Journal of Archaeology, 1980, vol. 84, no. 2, pp. 125-131.

Sarianidi V. Tilya Tepe: The Burial of a Noble Warrior. Persica, 1990-1992, vol. 14, pp. 103-130.

Schiltz V. Tillya Tepe, the Hill of Gold: a Nomad Necropolis. Afghanistan: Crossroads of the Ancient World. London, The British Museum Press, 2011, pp. 219-293.

Schmidt E. Persepolis I: Structures, Reliefs, Inscriptions. Chicago, The University of Chicago Press, 1953, $297 \mathrm{p}$.

Schmidt E. Persepolis III: The Royal Tombs and Other Monuments. Chicago, The University of Chicago Press, 1970, $174 \mathrm{p}$.

Sekunda N. Hellenistic Infantry Reform in the 160’s BC. Lodz, Oficyna Naukowa, 2001, 189 p.

Shenkar M. Intangible Spirits and Graven Images: The Iconography of Deities in the Pre-Islamic Iranian World. Leiden, Boston, Brill, 2014, 392 p.

Shenkar M. The Headdress of the Tillya Tepe "Prince". Ancient Civilizations from Scythia to Siberia, 2017, vol.23, pp. 151-183.

Skupniewicz P. Bóg Skanda-Kartikeia w ikonografii Gandhary. İstoriâ religij v Ukraïnì naukovij ŝoričnik, 2017, vol.27.2, pp. 95-103.

Skupniewicz P. Some Remarks on the Elements of Infantry Protective Gear in Art of Gandhara: An Evidence for Survival of Hellenistic Military Tradition? Metamorphoses of History, 2016, vol. 7, pp. 39-66.

Skupniewicz P. The Iconographic Function of Armor in Sasanian Art. Rivista degli Studi Orientali, Nuova Serie, 2016, vol. 88, fasc. 1-4, pp. 251-281.

Skupniewicz P., Maksymiuk K. Gordāfarid, Penthesilea and Athena: the identification of a Greek motif in Ferdowsīs Šāh-nāma and its possible association with Hellenistic art in the East. Mediterranean Historical Review, 2019, vol.34, iss. 2, pp. 123-143.

Stančo L. Greek Gods in the East: Hellenistic Iconographic Schemes in Central Asia. Prague, Karolinum Press, 2012, $262 \mathrm{p}$.

Tadmor M. Fragments of an Achaemenid Throne from Samaria. Israel Exploration Journal, 1974, vol.24, no. 1, pp. 37-43.

Treister M. New Discoveries of Sarmatian Burials of the $1^{\text {st }}$ Century A.D. A Survey of Publications in VDI. Ancient Civilizations from Scythia to Siberia, 1998, vol. 4, iss. 1, pp. 35-100.

Статья поступила в редакцию 2 марта 2020 г.

Рекомендована в печать 12 марта 2021 г.

Received: March 02, 2020

Accepted: March 12, 2021 